\title{
A NOTE ON TRANSLATION AND TRANSLITERATION
}

Unless otherwise indicated, all translations from Hebrew and Aramaic are mine. In preparing the translations of biblical and rabbinic texts, I have consulted published translations of these texts and translations of them quoted in books and articles by writers to whom I refer throughout the book.

The transliteration of Hebrew and Aramaic is based on the "general" transliteration style for Hebrew of Encyclopaedia Judaica, $2^{\text {nd }}$ Edition, edited by Michael Berenbaum and Fred Skolnik (Detroit: Macmillan Reference USA, 2007), with some modifications. Some words are spelled according to common usage in English, even when the spelling differs from the Encyclopaedia Judaica transliteration style. 